OPEN ACCESS

Edited by:

Verónica Chico Gras,

Universidad Miguel Hernández de

Elche, Spain

Reviewed by:

Junfa Yuan,

Huazhong Agricultural University,

China

Chengyu Hu,

Nanchang University, China

*Correspondence:

Shao-Wen Wang

wangsw@scau.edu.cn

Qi-Wei Qin

qinqw@scau.edu.cn

Hong-Yan Sun

hongyanlucky@scau.edu.cn

Specialty section:

This article was submitted to Comparative Immunology, a section of the journal

Frontiers in Immunology

Received: 31 August 2021 Accepted: 19 October 2021 Published: 10 November 2021

Citation:

Li P-H, Wang L-Q, He J-Y, Zhu X-L, Huang W, Wang S-W, Qin Q-W and Sun H-Y (2021) MicroRNA-124

Promotes Singapore Grouper Iridovirus Replication and Negatively Regulates Innate Immune Response.

Front. Immunol. 12:767813. doi: 10.3389/fimmu.2021.767813

\section{MicroRNA-124 Promotes Singapore Grouper Iridovirus Replication and Negatively Regulates Innate Immune Response}

\author{
Pin-Hong Li ${ }^{1}$, Li-Qun Wang ${ }^{1}$, Jia-Yang He ${ }^{1}$, Xiang-Long Zhu ${ }^{1}$, Wei Huang ${ }^{1}$, \\ Shao-Wen Wang ${ }^{1 *}$, Qi-Wei Qin ${ }^{1,2,3^{*}}$ and Hong-Yan Sun ${ }^{1 *}$ \\ 1 University Joint Laboratory of Guangdong Province, Hong Kong and Macao Region on Marine Bioresource Conservation \\ and Exploitation, College of Marine Sciences, South China Agricultural University, Guangzhou, China, ${ }^{2}$ Southern Marine \\ Science and Engineering Guangdong Laboratory, Zhuhai, China, ${ }^{3}$ Laboratory for Marine Biology and Biotechnology, \\ Qingdao National Laboratory for Marine Science and Technology, Qingdao, China
}

Viral infections seriously affect the health of organisms including humans. Now, more and more researchers believe that microRNAs (miRNAs), one of the members of the noncoding RNA family, play significant roles in cell biological function, disease occurrence, and immunotherapy. However, the roles of miRNAs in virus infection (entry and replication) and cellular immune response remain poorly understood, especially in low vertebrate fish. In this study, based on the established virus-cell infection model, Singapore grouper iridovirus (SGIV)-infected cells were used to explore the roles of miR-124 of Epinephelus coioides, an economically mariculture fish in southern China and Southeast Asia, in viral infection and host immune responses. The expression level of $E$. coioides miR-124 was significantly upregulated after SGIV infection; miR-124 cannot significantly affect the entry of SGIV, but the upregulated miR-124 could significantly promote the SGIV-induced cytopathic effects (CPEs), the viral titer, and the expressions of viral genes. The target genes of miR-124 were JNK3/p38 $\alpha$ mitogen-activated protein kinase (MAPK). Overexpression of miR-124 could dramatically inhibit the activation of NF- $\mathrm{kB}$ /activating protein-1 (AP-1), the transcription of proinflammatory factors, caspase-9/3, and the cell apoptosis. And opposite results happen when the expression of miR-124 was inhibited. The results suggest that $E$. coioides miR-124 could promote viral replication and negatively regulate host immune response by targeting JNK3/p38 $\alpha$ MAPK, which furthers our understanding of virus and host immune interactions.

Keywords: miR-124, Epinephelus coioides, SGIV, viral replication, immune response

\section{INTRODUCTION}

Viral infections seriously affect the health of organisms including humans. It is important to study the mechanism of viral infection and control the processing of diseases induced by virus. Singapore grouper iridovirus (SGIV) belonging to genus Ranavirus, family Iridoviridae, is a double-stranded DNA virus with icosahedral symmetry and a diameter of $120-200 \mathrm{~nm}$ (1). As a high pathogenic 
virus of marine fish, SGIV can induce mortality rates of more than $90 \%$ and cause major economic losses of the aquaculture (2-6). It is important to clear the SGIV life cycle and the relationship between viral infection and host immunity for controlling the disease induced by SGIV. In recent years, the researchers found that some non-coding RNA could be involved in SGIV infection and replication $(7,8)$.

MicroRNAs (miRNAs) are small non-coding RNAs with about 22-25 nucleotides in length (9). Since miRNA was found in the embryonic development of Caenorhabditis elegans, multiple roles of miRNA were gradually demonstrated (10-12). By binding to the $3^{\prime}$ untranslated region (UTR) of mRNA, miRNA can regulate the translation and expression of genes to affect the processing of proliferation, metabolism, apoptosis, immunity, growth, and plasticity of neurons, etc. (13-15). MiRNAs can also regulate viral replication by adjusting innate immune response or apoptosis of host (16): miR-214 enhances the expression of the target gene AMPK and promotes Snakehead vesiculovirus (SHVV) replication by reducing the expression of type I interferon regulator (17); miR-731 can increase Cytomegalovirus replication in the early stage of infection by inhibiting the expression of IRF7 and p53, IFN-I response, cell apoptosis, and cell cycle arrest (18).

In mammals, miR-124 participates in the development and progression of cancer, nervous system, and host-pathogen: miR124 inhibits cell proliferation in hepatocellular carcinoma by targeting PIK3CA and plays important roles in many cancers via the inhibition of PI3K/Akt pathway (19); miR-124 in the brain plays a key role in neurogenesis, neuronal differentiation, and synaptic plasticity in adults $(20,21)$; and miR-124 has a broad spectrum antiviral activity against influenza $A$ virus (IAV) and respiratory syncytial virus (RSV) (22). To date, whether miR-124 affects the entry of virus remains unknown. In low vertebrate fish, the roles of miR-124 in the interactions of virus and host immune response need to be explored.

Epinephelus coioides is an economically mariculture fish in southern China and Southeast Asia, and SGIV can kill large numbers of E. coioides in a short time (1-6). Based on this information, the aim of this study was to explore the expression pattern of miR-124 response to SGIV infection; the role of miR124 in the entry of SGIV, viral titers, and the expressions of viral genes; and immune response of host SGIV-induced cell apoptosis.

\section{MATERIALS AND METHODS}

\section{Cells, Virus, and MicroRNAs}

The E. coioides spleen cells (GS cells, College of Marine Sciences, South China Agricultural University, China) were established in culture medium with $10 \%$ fetal bovine serum (Gibco, USA) at $28^{\circ} \mathrm{C}$ in Leibovitz's L-15 medium (Gibco, USA). Because of the source, GS cells are good for studying the functions of E. coioides miRNAs $(8,23)$. Because SGIV cannot induce typical apoptosis in GS cells, the fathead minnow (FHM) cells have been verified to be good for analyzing SGIV-induced apoptosis $(8,23,24)$. FHM cells herein were used for apoptosis analysis. FHM cells were cultured in Leibovitz's L-15 medium (Gibco, USA) embodying $10 \%$ fetal bovine serum (Gibco, USA) at $28^{\circ} \mathrm{C}(8,23,24)$. SGIV used for viral-infection experiments was originally obtained by our lab as previously described (1). The miRNAs, including control mimics, miR-124 mimics, control inhibitors, and miR124-specific inhibitors, were purchased from RiboBio (China).

\section{Total RNA Extraction and cDNA Synthesis}

The RNA was isolated from E. coioides tissues from the liver, spleen, intestine, trunk kidney, gills, head kidney, skin, muscle, brain, and heart using TRIzol reagent (Invitrogen, Canada) and purified with DNase I (Promega, USA). RNA from the GS cells infected by SGIV was isolated using TRIzol reagent according to the manufacturer's instruction. The cDNA was synthesized using ReverTra Ace kit (Toyobo, Japan), and the specific miR-124 reverse transcription was obtained using miRNA RT kit (RiboBio, China). The reverse transcription was performed in a final volume of $20 \mu \mathrm{l}$ containing $4 \mu \mathrm{l}$ of $5 \times \mathrm{RT}$ buffer, $1 \mu \mathrm{l}$ of RT polymerase, $1 \mu \mathrm{l}$ of miR-124-specific RT primer, and $14 \mu \mathrm{l}$ of the denatured RNA. The reverse transcription condition was $42^{\circ} \mathrm{C}$ for $60 \mathrm{~min}$, followed by $70^{\circ} \mathrm{C}$ for $10 \mathrm{~min}$ and $4^{\circ} \mathrm{C}$ for $15 \mathrm{~min}$. The products obtained were used as a template in quantitative realtime PCR amplification (qPCR).

\section{Expression Analysis}

MiR-124 level was determined using Bulge-Loop ${ }^{\mathrm{TM}}$ miRNA qRT-PCR kit (RiboBio, China), and the U6 was used as the reference genes. qPCR was performed with SYBR Green RealTime PCR Master Mix (Toyobo) at Applied Biosystems QuantStudio 5 Real Time Detection System (Thermo Fisher, USA). The reaction system was $10 \mu \mathrm{l}$ including $5 \mu \mathrm{l}$ of SYBR qPCR mix, $0.3 \mu \mathrm{l}$ of forward and reverse bulge-loop miRNA primer, $3.4 \mu \mathrm{l}$ of PCR-grade water, and $1 \mu \mathrm{l}$ of diluted miR-124specific cDNA. The reaction condition was $95^{\circ} \mathrm{C}$ for $5 \mathrm{~min}$, followed by 40 cycles of $94^{\circ} \mathrm{C}$ for $5 \mathrm{~s}, 56^{\circ} \mathrm{C}$ for $10 \mathrm{~s}$, and $72^{\circ} \mathrm{C}$ for $15 \mathrm{~s}$. The expression of the genes was normalized to reference gene and calculated with the $2^{-\Delta \Delta \mathrm{Ct}}$ method.

\section{Western Blotting Analysis}

Cells were lysed in pierce IP lysis buffer (Thermo Fisher) and separated by $10 \%$ sodium dodecyl sulfate-polyacrylamide gel electrophoresis (SDS-PAGE); and after electrophoresis, the proteins were transferred onto polyvinylidene difluoride (PVDF) membranes (Millipore, USA). In our lab, 5\% bovine serum albumin (BSA) diluted rabbit anti-MCP antibody (1:1,000 dilution) was prepared, in which the patent number was CN111363758A (8). P-JNK3(1:1,000 dilution), P-p38 mitogenactivated protein kinase (MAPK) (1:1,000 dilution), caspase-3 (1:1,000 dilution), cleaved caspase-3 (1:1,000 dilution), and rabbit anti- $\beta$-tubulin antibody (1:2,000 dilution) was purchased from Abcam. Horseradish peroxidase (HRP)-conjugated goat anti-rabbit $(1: 5,000)$ was purchased from KPL (USA). And then we used the HRP-DAB Chromogenic Substrate Kit (Tiangen, China) to visualize according to the manufacturer's instructions and took photos. 


\section{Confocal Microscopy and Single-Particle Imaging Assay}

To explore the effect of miR-124 on the entry of SGIV, we explored the miR-124 on virus entry using confocal imaging. Fluorescence images were observed through ZEISS LSM 7 DUO confocal microscope. The fluorescent label, Alexa Fluor 647 (labelled SGIV), and 4\% paraformaldehyde were purchased from Invitrogen. The lipophilic dye, $\mathrm{DiO}$, which indicates the cell boundaries (green), was purchased from Biotium, USA. Fluorescence emission was collected and imaged through a $100 \times$ (numerical aperture, 1.4) oil immersion objective. A 488$\mathrm{nm}$ Ar-Kr laser was used to excite DiO signals, and a 500- to 550$\mathrm{nm}$ bandpass filter was used for emission. For quantification analysis, confocal images were obtained by noise filtering, edge detection, and fluorescence signal extraction using a MATLAB program. Approximately 60 cells were randomly analyzed by the MATLAB program to calculate the number of SGIV particles in the cytoplasm.

\section{The Cytopathic Effect}

To evaluate the effects of miR-124 on virus infection, control mimics, miR-124 mimics, control inhibitors, or miR-124 inhibitors $(100 \mathrm{nM})$ were transfected into GS cells in 24-well plates using Lipofectamine RNAiMAX (Invitrogen, USA) according to the manufacturer's instructions. Twenty-four hours after transfection, the cells were then infected with SGIV for 12-h point infection, and photos of the cell morphology were taken.

\section{Virus Titer Assay}

To detect the effect of miR-124 on SGIV production, the viral titer was evaluated by $\mathrm{TCID}_{50}$ analysis. GS cells were transfected with the miR-124 mimics (100 nM) in 24-well plates for $24 \mathrm{~h}$ and then infected with SGIV for $24 \mathrm{~h}$. Cells were collected and freezethawed three times at $-80^{\circ} \mathrm{C}$. The cell lysate was then serially diluted and used for GS cell infection in 96-well plates. About 6 days after infection, the viral titer was calculated using $\mathrm{TCID}_{50}$ analysis.

\section{Virus Gene Analysis}

To evaluate the effects of miR-124 on virus infection, the miRNAs $(100 \mathrm{nM})$ were transfected into GS cells in 12-well plates. Twenty-four hours after transfection, the cells were infected with SGIV for $24 \mathrm{~h}$, and then the expressions of the viral genes (MCP, VP19, ICP18, and LITAF) were detected by RT-qPCR with the $\beta$-actin as the reference gene. And the Western blotting analysis was used to detect the protein synthesis of SGIV MCP.

\section{Plasmid Construction}

According to the transcriptome data and the BLAST information, the GenBank accession numbers of JNK3 and p38 $\alpha$ MAPK were KT385696.1 and JN408831.1, respectively. The primers JNK3-3' UTR-F/JNK3-3' UTR-R, and p38 $\alpha-3^{\prime}$ UTR-F/p38 $\alpha-3^{\prime}$ UTR-R (Table 1), were designed to amplify JNK3-3'UTR and p38 $\alpha-3^{\prime}$ UTR cDNA. PCR in a final volume of $25 \mu \mathrm{l}$ was as follows: $1 \mu \mathrm{l}$ of template DNA, $1 \mu \mathrm{l}$ of each primer, $12.5 \mu \mathrm{l}$ of LA Taq polymerase (Takara), and $9.5 \mu \mathrm{l}$ of $\mathrm{H}_{2} \mathrm{O}$. The conditions for PCR amplification were as follows: 34 cycles of $94^{\circ} \mathrm{C}, 30 \mathrm{~s} ; 57^{\circ} \mathrm{C}, 30 \mathrm{~s}$; and $72^{\circ} \mathrm{C}, 30 \mathrm{~s}$, followed by $72^{\circ} \mathrm{C}$ for $5 \mathrm{~min}$. The PCR products were purified and cloned into pmiR-RBReport $^{\mathrm{TM}}$ (RiboBio, China). The restriction sites are XhoI and NotI. And the recombinant plasmid (pmiR-JNK3 and pmiRp38 $\alpha$ ) was confirmed by DNA sequencing. And the primers JNK3-mut-3'UTR-F/JNK3-mut-3'UTR-R and p38 $\alpha$-mut-3' UTR-F/p38 $\alpha$-mut-3'UTR-R were designed to make mutant plasmid (pmiR-mut-JNK3 and pmiR-mut-p38 $\alpha$ ).

\section{MicroRNA Target Prediction}

The RNAhybrid (https://bibiserv.cebitec.uni-bielefeld.de/ rnahybrid), TargetScan (http://www.targetscan.org/cgi-bin/), and miRanda (http://www.microrna.org/microrna/) were used to predict the putative targets of miR-124. And the $3^{\prime}$ UTR regions of the target gene of miR-124 of grouper immune-related genes were collected from the National Center for Biotechnology Information (NCBI) database (https://www.ncbi.nlm.nih.gov/).

To analyze the relationship between miR-124 and the gene JNK3/p38 $\alpha$ MAPK, GS cells were co-transfected with miR-124 mimics/control mimics (100 nM), luciferase reporter vector (pmiRJNK3/pmiR-p38 $\alpha$ MAPK, 800 ng), and (pmiR-mut-JNK3/pmiRmut-p38 $\alpha$ MAPK, $800 \mathrm{ng}$ ) in 24-well plates for $24 \mathrm{~h}$. Luciferase activity was detected using the Dual-Luciferase Reporter Assay system (Promega, USA). The specificity of target was ascertained by the relative luciferase activity of Firefly/Renilla.

\section{Dual Luciferase Reporter Assays}

In order to verify the role of miR-124 in the transcriptional regulation of NF- $\kappa \mathrm{B}$ and activating protein-1 (AP-1), control mimics, miR-124 mimics, control inhibitors, or miR-124 inhibitors $(100 \mathrm{nM})$ were co-transfected with $150 \mathrm{ng}$ of NF$\kappa \mathrm{B} / \mathrm{AP}-1$-dependent firefly luciferase reporter plasmid and $40 \mathrm{ng}$ of Renilla luciferase vectors into GS cells at 24-well plates using luciferase reporter assay for $24 \mathrm{~h}$. The cells were infected with SGIV for $12 / 24 \mathrm{~h}$ and harvested using the Dual-Luciferase ${ }^{\circledR}$ Reporter Assay System (Promega, USA) to measure the luciferase activities according to the manufacturer's instructions.

\section{Cell Apoptosis Analysis}

It was demonstrated that SGIV can induce the typical apoptosis in FHM cells (24). To explore the function of miR-124 in SGIV-induced cell apoptosis, control mimics, miR-124 mimics, control inhibitors, and miR-124 inhibitors at $100 \mathrm{nM}$ were transfected into FHM cells for 24-well plates by three replicates. After $24 \mathrm{~h}$ of SGIV infection, the cells were harvested, and the apoptosis was detected by both the terminal deoxy nucleotidyl transferase (TdT)-mediated dUTP nickend labeling (TUNEL) assay using fluorescence microscope and flow cytometry using the Annexin V-FITC apoptosis detection kit (Beyotime, China) according to the manufacturer's instructions. Each sample was analyzed in triplicate. Data acquisition and analysis were performed using a flow cytometry system (Beckman Coulter, USA) and FlowJo VX software.

\section{Caspase-9/3 Activity Analysis}

To detect the effect of miR-124 in caspase-9/3 activity, the Caspase Fluorometric assay kit (BioVision, USA) was used to 
TABLE 1 | The primers of this study.

\begin{tabular}{|c|c|}
\hline Primer & Sequence $\left(5^{\prime}-3^{\prime}\right)$ \\
\hline$\beta$-Actin-R & CCTTGATGTCACGCACGAT \\
\hline VP19-RT-R & GGGGTAAGCGTGAAGACT \\
\hline LITAF-RT-F & GATGCTGCCGTGTGAACTG \\
\hline LITAF-RT-R & GCACATCCTTGGTGGTGTTG \\
\hline MCP-RT-F & GCACGCTTCTCTCACCTTCA \\
\hline ICP18-RT-R & CCGTCGTCGGTGTCTATTC \\
\hline JNK3-RT-F & CCAGGACCGCAGGCACCAGTT \\
\hline JNK3-RT-R & GTGGCGCACCATTTCTCCCATAA \\
\hline $\mathrm{p} 38 \alpha-\mathrm{RT}-\mathrm{F}$ & CCTCAACAACATCGTCAAGTG \\
\hline $\mathrm{p} 38 \alpha-\mathrm{RT}-\mathrm{R}$ & GGCTTCAAGTCTCTGTGGAT \\
\hline JNK3-3'UTR-F & СССТCGAGCССССССТССТССТССАТАA \\
\hline JNK3-mut-3'UTR-R & TाTATTGCGGCCAGCGGCCGCCCTTACGCGCCATAGTCACCTGCAACAC \\
\hline p38 $\alpha-m u t-3{ }^{\prime} U T R-F$ & AATTCTAGGCGATCGCTCGAGCAGAACCATGAGTAAGTACACGGAGCCGTC \\
\hline p38 $\alpha-m u t-3$ 'UTR-R & TाTATTGCGGCCAGCGGCCGCCAG \\
\hline TNF $\alpha-R T-F$ & GTGTCCTGCTGTTTGTTGGTA \\
\hline TNF $\alpha-R T-R$ & CAGTGTCCGACTTGATTAGTGCTT \\
\hline IL-6-RT-F & СTCTACACTCAACGCGTACATGC \\
\hline IL-6-RT-R & TCATCTTCAAACTGCTITCGTG \\
\hline IL-8-RT-F & GCCGTCAGTGAAGGGAGTCTAG \\
\hline IL-8-RT-R & ATCGCAGTGGGAGTTTGCA \\
\hline IL-1 $\beta-R T-F$ & AАCCTCATCATCGCCACACA \\
\hline IL-1 $\beta-R T-R$ & AGTTGCCTCACAACCGAACAC \\
\hline
\end{tabular}

test the activity of caspase- $9 / 3$ according to the manufacturer's instructions. FHM cells at 24-well plates transfected with $100 \mathrm{nM}$ of control mimics, miR-124 mimics, control inhibitors, or miR124 inhibitors were infected by SGIV for $24 \mathrm{~h}$. The cells were lysed in $50 \mu \mathrm{l}$ of cold lysis buffer on ice for $10 \mathrm{~min}$ and centrifuged at 1,800 rpm for $3 \mathrm{~min}$, and the supernatant was retained. The reaction system was prepared: $50 \mu \mathrm{l}$ of the supernatant, $50 \mu \mathrm{l}$ of $2 \times$ reaction buffer, $5 \mu \mathrm{l}$ of caspase- $9 / 3$ fluorogenic substrate (LEHD-AFC/DEVD-AFC), and $0.5 \mu \mathrm{l}$ of fresh DTT. After incubation at $37^{\circ} \mathrm{C}$ for $1 \mathrm{~h}$, fluorescence was measured (excitation $400 \mathrm{~nm}$, excitation $505 \mathrm{~nm}$ ) by Thermo Scientific ${ }^{\mathrm{TM}}$ Varioskan $^{\mathrm{TM}}$ LUX (Thermo Fisher, USA).

\section{Statistical Analysis}

All of the data expressed as mean \pm standard error of the mean (SD) were analyzed with GraphPad Prism 7.0 software using one-way ANOVA followed by Duncan's test. Significance was set at $p<0.05$.

\section{RESULTS}

\section{MiR-124 Is Upregulated by Singapore Grouper Iridovirus Infection}

E. coioides miR-124 was obtained by employing the Solexa deep sequencing approach in our lab (7). As shown in Table 2, the sequence was the same except for a difference of 2 or 3 bases in the end of $3^{\prime}$ end in the species, indicating that miR-124 is highly conserved between species.

To obtain the tissue-specific distribution profiles of E. coioides miR-124, the total RNA of the 10 tissues from healthy E. coioides was extracted, and qPCR was used to quantify the expression of E. coioides miR-124. MiR-124 was detected in all of the tissues, and the miR-124 was specifically expressed in the brain, followed by the heart, intestine, skin, liver, gills, muscle, spleen, trunk kidney, and head kidney (Figure 1A).

In order to characterize the expression profile of miR-124 after SGIV infection, the expression of miR-124 under the stimulation of SGIV was examined by qPCR. The expression of miR-124 was upregulated during the SGIV infection (Figure 1B) $(p<0.05)$.

\section{MiR-124 Promoted the Singapore Grouper Iridovirus Replication}

To examine the efficiency of miR-124 mimics or inhibitors, the expression of miR-124 of the GS cells transfected with miR-124 mimics $(100 \mathrm{nM})$ or inhibitors $(100 \mathrm{nM})$ for 24 and $48 \mathrm{~h}$ was examined. As shown in Figure 2A, the significantly higher expression of miR-124 was detected in the cells with the miR124 mimics for $48 \mathrm{~h}(p<0.05)$, and the miR-124 was significantly downregulated in the cells transfected with the miR-124 inhibitor for $48 \mathrm{~h}$ (Figure 2B) $(p<0.05)$, showing that it is still efficient at $48 \mathrm{~h}$ post transfection with miR-124 mimics or inhibitor. 
TABLE 2 | Sequence of miR-124 in different species.

\begin{tabular}{|c|c|c|c|}
\hline MiRNA name & Sequence $\left(5^{\prime}-3^{\prime}\right)$ & Species & miRBase number \\
\hline eco-miR-124 & UAAGGCACGCGGUGAAUGCCAA & Epinephelus coioides & Undetermined \\
\hline dre-miR-124 & UAAGGCACGCGGUGAAUGCCAA & Danio rerio & MIMAT0001819 \\
\hline hsa-miR-124-3p & UAAGGCACGCGGUGAAUGCCAA & Homo sapiens & MIMAT0000422 \\
\hline bta-miR-124a & UAAGGCACGCGGUGAAUGCCAAG & Bos taurus & MIMAT0003811 \\
\hline dme-miR-124-3p & UAAGGCACGCGGUGAAUGCCAAG & Drosophila melanogaster & MIMAT0000351 \\
\hline cfa-miR-124 & UAAGGCACGCGGUGAAUGCCA & Canis familiaris & MIMAT0006657 \\
\hline mmu-miR-124-3p & UAAGGCACGCGGUGAAUGCC & Mus musculus & MIMAT0000134 \\
\hline rno-miR-124-3p & UAAGGCACGCGGUGAAUGCC & Rattus norvegicus & MIMAT0000828 \\
\hline
\end{tabular}

The red font indicates completely the same sequence.

To explore the effect of miR-124 on the entry of SGIV, virus entry in the cells transfected with miR-124 mimics was analyzed using confocal imaging. Compared with the cells transfected with the control mimics, cells transfected with miR-124 mimics were not significantly different on SGIV entry (Figures 3A, B), suggesting that miR-124 might not be involved in the entry of SGIV.

The GS cells transfected with miR-124 mimics were infected with SGIV for $24 \mathrm{~h}$. Subsequently, the SGIV-induced cytopathic effects (CPEs), the SGIV production, and expression of the viral genes were analyzed. And the CPE was increased in the cells transfected with miR-124 mimics and decreased in the cells transfected with miR-124 inhibitor (Figure 4A). The viral titer, which was used to evaluate viral production, of the miR-124 overexpression cells was significantly higher than that of the control cells, while that of the miR-124 downregulated cells was significantly lower than that of the control cells (Figure 4B) $(p<0.05)$. Furthermore, the transcription levels of SGIV genes (MCP, VP19, ICP18, and LITAF) were examined. The expression of viral genes $M C P, V P 19$, ICP18, and LITAF were

A
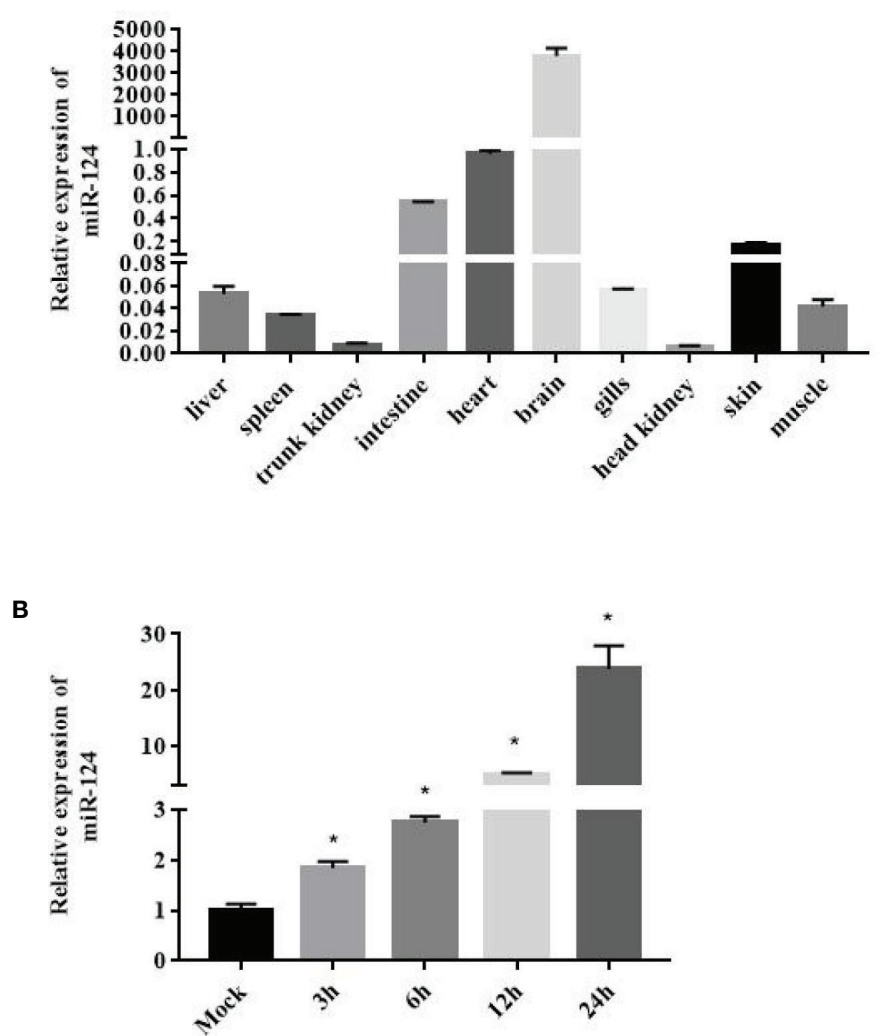

FIGURE 1 | Expression of miR-124 in tissues and in response to Singapore grouper iridovirus (SGIV) infection in the GS cell. (A) Expression of miR-124 was detected in the 10 tissues. Data are presented as mean $\pm S D, N=3$. (B) Expression of miR-124 in response to SGIV infection in the GS cell. The GS cells were incubated in 24-well plates and after $24 \mathrm{~h}$ were infected by SGIV. U6 was used as internal reference. The control and SGIV infection groups of the miR-124 expression significant differences at each time points are indicated with * $(p<0.05)$. Data are presented as mean $\pm S D, N=4$. 
A
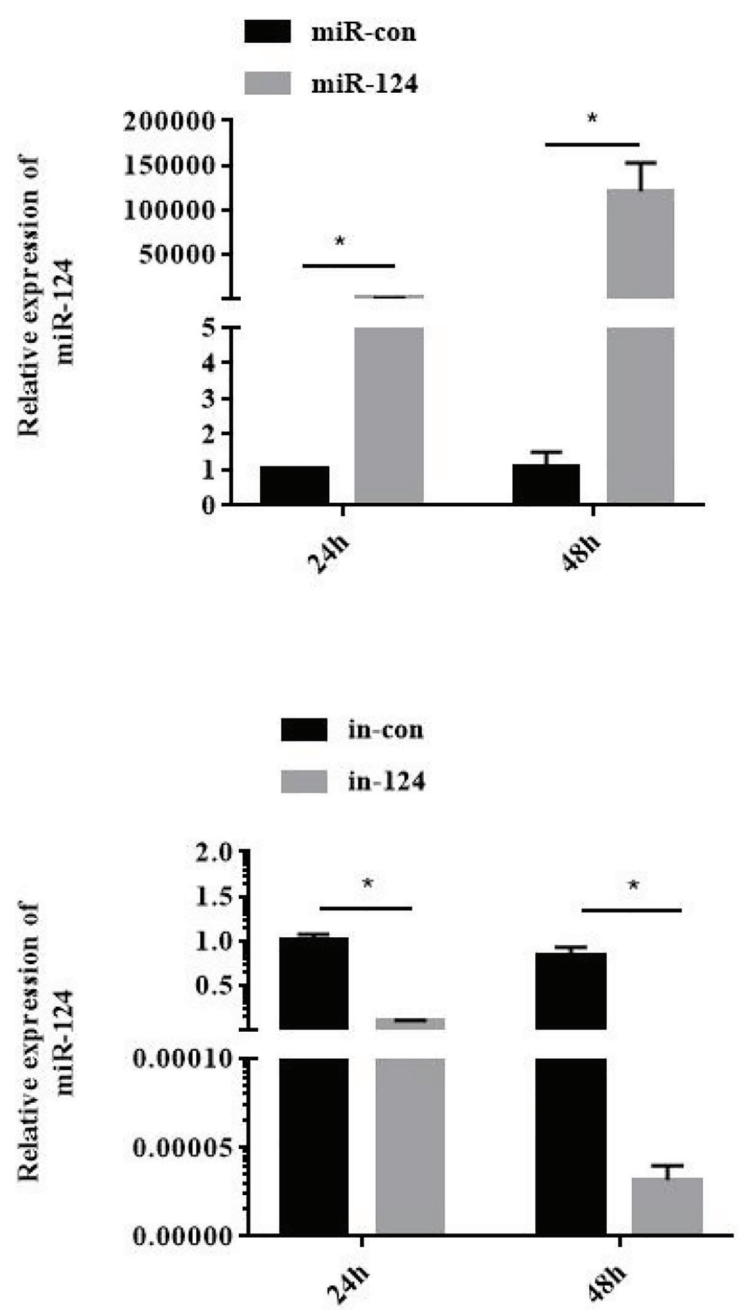

FIGURE 2 | Efficiency detection of miR-124 overexpression. 100nM control mimics (A), miR-124 mimics (A), control inhibitors (B), or miR-124 inhibitors (B) were transfected into the GS cells in 12 well plate. The cells at $24 \mathrm{~h}$ and $48 \mathrm{~h}$ was collected and the expression of miR-124 was detected. U6 was used as internal reference. Control mimics, miR-con; miR-124 mimics, miR-124; control inhibitors, in-con; miR-124 inhibitors, in-124. All data are presented as Mean \pm SD, $\mathrm{N}=4$. Compared with the control group, significant difference of experimental group is indicated with * $(P<0.05)$.

significantly upregulated in the cells transfected with miR-124 mimics, which were downregulated in the cells transfected with miR-124 inhibitor (Figures 4C-F). By Western blotting, the protein level of MCP in the cells transfected with miR-124 mimics (1.30) was higher than that of the control group (0.94), while the protein level of MCP in the cells transfected with miR-124 inhibitor (0.78) was lower than that of the control group (1.18) (Figure 4G), showing that overexpression of miR124 could enhance the protein synthesis of SGIV MCP and that inhibited miR-124 could decrease the synthesis of MCP.

\section{MiR-124 Regulates Innate Immune Response of Epinephelus coioides}

By bioinformatics tools, JNK3 and p38 $\alpha$ MAPK were the putative target genes of miR-124, and the binding energy value was -27.1 and $-24.4 \mathrm{kcal} / \mathrm{mol}$, respectively. The miR-124 sequence contains a conserved sequence matching the JNK3/ p38 $\alpha$ MAPK binding $3^{\prime}$-UTR (Figures 5A, B). To study the role miR-124 on JNK3 and p38 $\alpha$ MAPK, the JNK3 and p38 $\alpha$ MAPK mRNAs were examined in the overexpression miR-124 cells by qPCR. The expressions of both JNK3 and p38 $\alpha$ MAPK in the cells transfected with miR-124 mimics were significantly downregulated than those in the control groups (Figures $5 \mathrm{C}, \mathrm{D}$ ) $(p<0.05)$. To verify the relationship of JNK $3 / \mathrm{p} 38 \alpha$ MAPK and miR-124, JNK3/p38 $\alpha$ MAPK $3^{\prime}$-UTR or JNK3/p38 $\alpha$ MAPK mutant $3^{\prime}$-UTR was cloned into a luciferase reporter vector pmiR-RB-Report. The GS cells transfected with the luciferase reporter containing miR-124 mimics and JNK3/p38 $2 \mathrm{MAPK}$ wild $3^{\prime}$-UTR or JNK3/p38 $\alpha$ MAPK mutant $3^{\prime}$-UTR were analyzed. The luciferase activities were significantly reduced in 
A

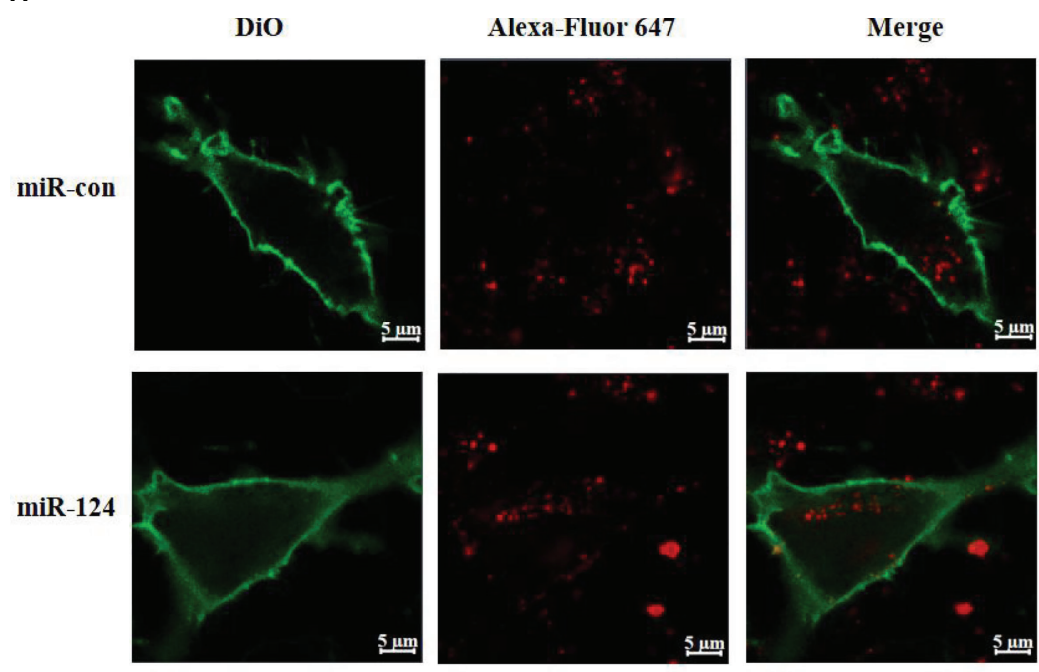

B

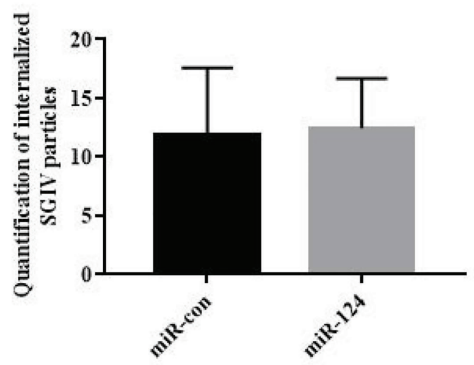

FIGURE 3 | The effect of miR-124 on the entry of Singapore grouper iridovirus (SGIV). (A) Three-dimensional confocal images of SGIV attachment in control mimics (miR-con) or miR-124 mimics (miR-124) transfected cells. The samples were stained with DiO to show the cell boundaries (green). The SGIV was labeled Alexa Fluor 647 (red). Scale bars represent $5 \mu \mathrm{m}$. (B) Quantification of internalized SGIV particles. Over 60 cells were randomly selected and analyzed by MATLAB program. The data are indicated as mean $\pm \mathrm{SD}, \mathrm{N}=60$.

the cells containing JNK3/p38 $\alpha$ MAPK wild $3^{\prime}$-UTR (Figures 5E, F) $(p<0.05)$, and there was no significant change in the cells of JNK3/p38 $\alpha$ MAPK mutant $3^{\prime}$-UTR $(p<0.05)$. And the protein level of P-JNK3/P-p38 $\alpha$ MAPK in the cells transfected with miR-124 mimics (0.33 and 0.48) was lower than that of the control group (0.49 and 0.71) (Figures 5G, H).

To study the effect of miR-124 on the transcriptional activity of NF- $\kappa \mathrm{B}$ and AP-1, the control mimics, miR-124 mimics, control inhibitors, and miR-124 inhibitors at $100 \mathrm{nM}$ were transfected into GS cells for $24 \mathrm{~h}$; and then the cells were infected with SGIV and collected at 12 and $24 \mathrm{~h}$ post infection. The activations of the NF- $\mathrm{KB}$ and AP-1 were significantly reduced in the cells transfected with miR-124 mimics $(p<$ 0.05 ), and those of the NF- $\mathrm{KB}$ and AP-1 were significantly upregulated in the cells transfected with miR-124 inhibitor compared with the control group $(p<0.05)$ (Figures 6A, B).

To verify the roles of miR-124 in innate immunity, GS cells transfected with control mimics/miR-124 mimics/control inhibitors/miR-124 inhibitors were infected with SGIV, and the expressions of the proinflammatory factors TNF- $\alpha$, IL- 6 , IL- 8 , and IL- $1 \beta$ were detected. The expressions of these factors in the cells transfected with miR-124 mimics were significantly lower than those in the control group; those of the miR-124 inhibitors were significantly higher those of the control inhibitor (Figure 7) $(p<0.05)$, suggesting that miR-124 significantly reduced the transcription levels of the E. coioides immune-related factors.

\section{MiR-124 Inhibited the Singapore Grouper Iridovirus-Induced Cell Apoptosis}

SGIV infection can cause cell apoptosis in FHM cells (8). To explore the influence of miR-124 on SGIV-induced cell apoptosis, miR-124 mimics/control mimics/control inhibitors/ miR-124 inhibitors were transfected into FHM cells, and the cells were infected by SGIV for $24 \mathrm{~h}$. Subsequently, the cells were harvested, and the apoptosis was analyzed.

By TUNEL assay, the fractured DNA was labeled using fluorescein isothiocyanate (FITC)-conjugated UTP. The 
A
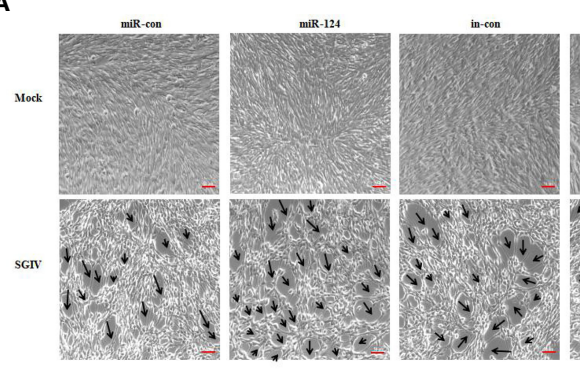

B
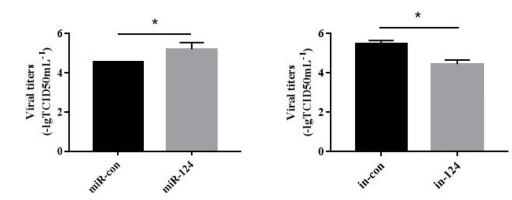

C
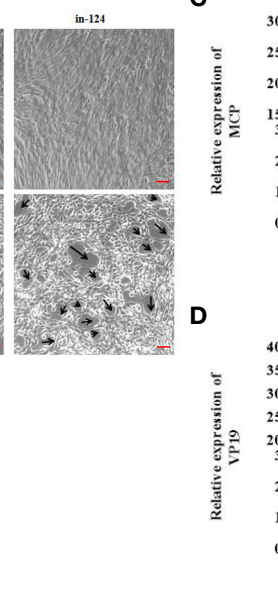
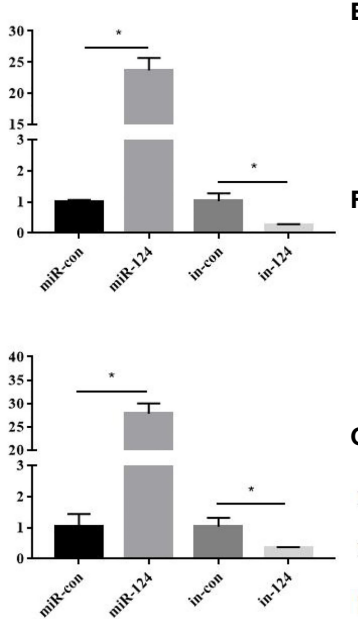

E
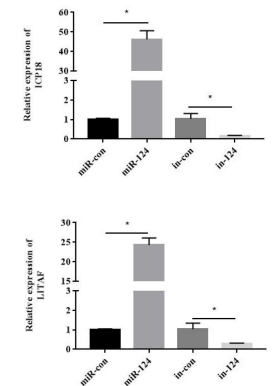

G

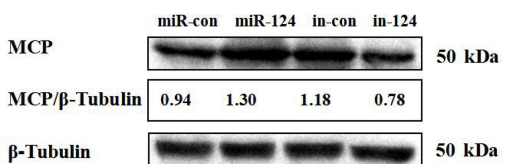

FIGURE 4 | Effect of miR-124 on virus infection and replication. (A) The cytopathic effect (CPE) of Singapore grouper iridovirus (SGIV)-infected miRNA-transfected GS cells, and the black arrows indicate the severity of CPE caused by SGIV infection at $24 \mathrm{~h}$. The scale is $50 \mu \mathrm{m}$. (B) The viral titers in each group were measured using the $\mathrm{TCID}_{50}$ method. Data are presented as mean $\pm \mathrm{SD}, \mathrm{N}=3$. (C-F) The expression levels of SGIV genes (MCP, VP19, ICP18, and LITAF). Data are presented as mean $\pm \mathrm{SD}, \mathrm{N}=4$. Compared with the control group, significant difference of experimental group is indicated with * $P<0.05)$. (G) The level of SGIV MCP proteins was detected by Western blotting, the band intensity was calculated, and ratios of target protein/ $\beta$-tubulin were assessed by ImageJ software. Control mimics, miR-con; miR-124 mimics, miR-124; control inhibitors, in-con; miR-124 inhibitors, in-124.

apoptotic cells were counted with florescence microscope. As shown in Figure 8A, the fractured DNA fragments were decreased in the cells transfected with miR-124 mimics and increased in the cells transfected with miR-124 inhibitor. The apoptosis rates in the cells transfected with control mimics and miR-124 mimics were $27.0 \%$ and $12.7 \%$, respectively (Figure 8B). The apoptosis rates were $15.7 \%$ and $23.3 \%$ in the cells transfected with miR-124 inhibitor (Figure 8B).

Similar results occurred in the analysis of flow cytometry. By flow cytometry, the apoptosis rate (sum of early apoptosis and late apoptosis) in the cells transfected with control mimics or miR124 mimics was $74.0 \%$ or $55.2 \%$, respectively (Figures 8C, D). The apoptosis rate (sum of early apoptosis and late apoptosis) in control cells was $35.8 \%$ and $40.2 \%$ in the cells transfected with miR-124 inhibitor (Figures 8C, D).

By Western blotting, the protein level of caspase- 3 in the cells transfected with miR-124 mimics (0.29) was lower than that of the control group (0.68), while the protein level of caspase- 3 in the cells transfected with miR-124 inhibitor (0.39) was higher than that of the control group (0.29) (Figure 8E); the protein level of cleaved caspase-3 in the cells transfected with miR-124 mimics (0.27) was lower than that of the control group (0.40), while the protein level of cleaved caspase- 3 in the cells transfected with miR-124 inhibitor (0.46) was higher than that of the control group (0.45) (Figure 8F), showing that overexpression of miR-124 could decrease the protein of caspase- 3 and cleaved caspase- 3 and that inhibited miR-124 could enhance the protein of caspase- 3 and cleaved caspase- 3 . The activity of caspase- 9 and caspase- 3 in the cells transfected with miR-124 mimics was significantly inhibited, as compared with that in the control group (Figures 8G, $\mathbf{H})(p<0.05)$. The results indicated that miR-124 significantly suppressed SGIVinduced cell apoptosis.

\section{DISCUSSION}

It is well known viral infections seriously affect the health of organisms. To date, non-coding RNA as a key factor has been involved in multiple biological processing including its roles in the response to pathogen stimulates. Non-coding RNA and miRNA regulated many functions of cells, including proliferation, metabolism, apoptosis, immunity, growth, and plasticity of neurons (13-15). However, the relationship of miRNA such as miR-124 and the viral entry remains unknown. In this study, the roles of marine fish E. coioides miR-124 in the infection and replication of SGIV and the innate immune response of host were explored.

Except for the difference of 2 or 3 bases in the $3^{\prime}$ end, E. coioides miR-124 shares the same sequences with other species from worm to humans, suggesting that its roles in these species might be similar $(25,26)$. In mammals, miR-124 is closely related to brain development, function, and homeostasis (27-29). However, the brain controls the spleen to regulate the function of the immune system from top to bottom; a special brain-spleen connection was recognized, enhancing humoral response autonomously and displaying immune stimulation through physical behavior, which revealed the brain's control of adaptive immunity, and proposes the possibility of improving immune ability through behavioral intervention (30). Similarly, miR-124 here was specifically expressed in E. coioides brain. 
A

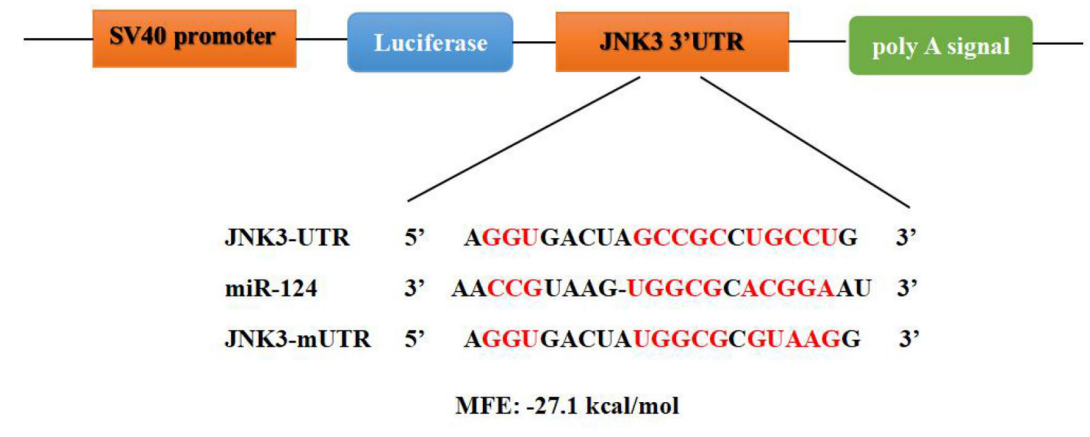

B



MFE: $-24.4 \mathrm{kcal} / \mathrm{mol}$

E

$$
\text { miR-con }
$$

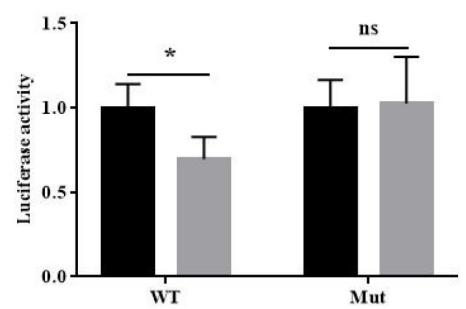

JNK3

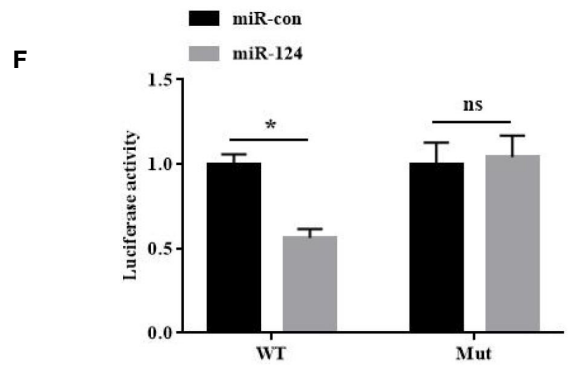

p38 $\alpha$ MAPK
G

P-JNK

P-JNK/ $\beta$-Tubulin

$\beta$-Tubulin

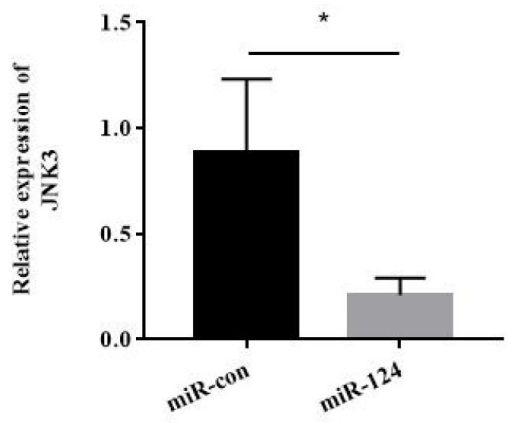

D

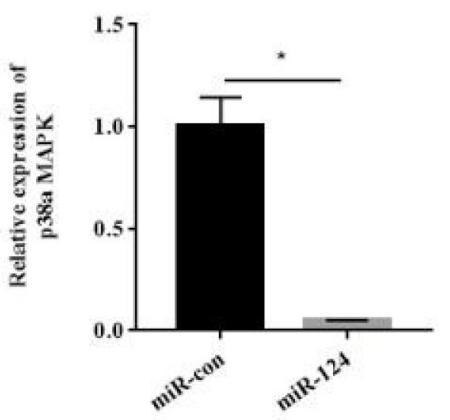

miR-con miR-124

$41 \mathrm{kDa}$
$0.49 \quad 0.33$

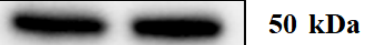

H

P-p38MAPK

miR-con miR-124

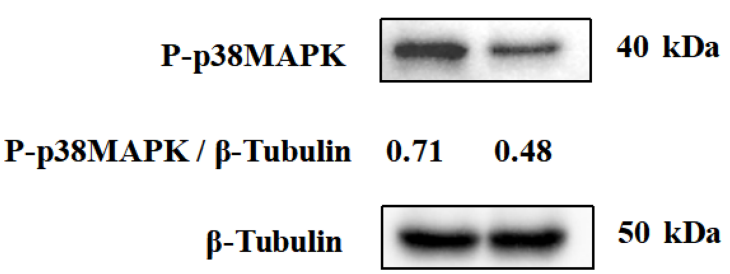

FIGURE 5 | JNK3 and p38 $\alpha$ MAPK were identified as the targets of miR-124. (A) Diagram of JNK3 3' UTR-containing reporter constructs. (B) Diagram of p38 $\alpha$ 3' UTR-containing reporter constructs. (C) The mRNA levels of JNK3 were reduced in GS cells treated with miR-124 mimics for $24 \mathrm{~h}$. Actin was used as internal reference. (D) The mRNA levels of $p 38 \alpha$ were reduced in GS cells treated with miR-124 mimics for $24 \mathrm{~h}$. $\beta$-Actin was used as internal reference. (E) The $3^{\prime}$ UTR reporter assay was performed in GS cells $24 \mathrm{~h}$ after transfection. (F) The 3' UTR reporter assay was performed in GS cells $24 \mathrm{~h}$ after transfection. (G) The level of P-JNK3 proteins was detected by Western blotting, the band intensity was calculated, and ratios of target protein/ $\beta$-tubulin were assessed by ImageJ software. (H) The level of P-p38 MAPK proteins was detected by Western blotting, the band intensity was calculated, and ratios of target protein/ $\beta$-tubulin were assessed by ImageJ software. Control mimics, miR-con; miR-124 mimics, miR-124; control inhibitors, in-con; miR-124 inhibitors, in-124. All data are presented as mean \pm SD, $N=4$. Compared with the control group, significant difference of experimental group is indicated with ${ }^{*}(P<0.05)$, and no significant difference is indicated with ns $(P>0.05)$. 
A

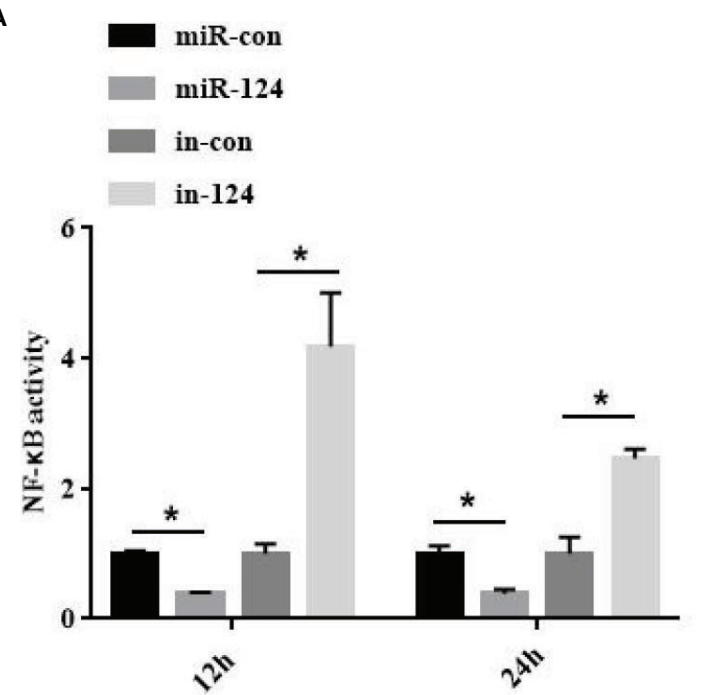

B
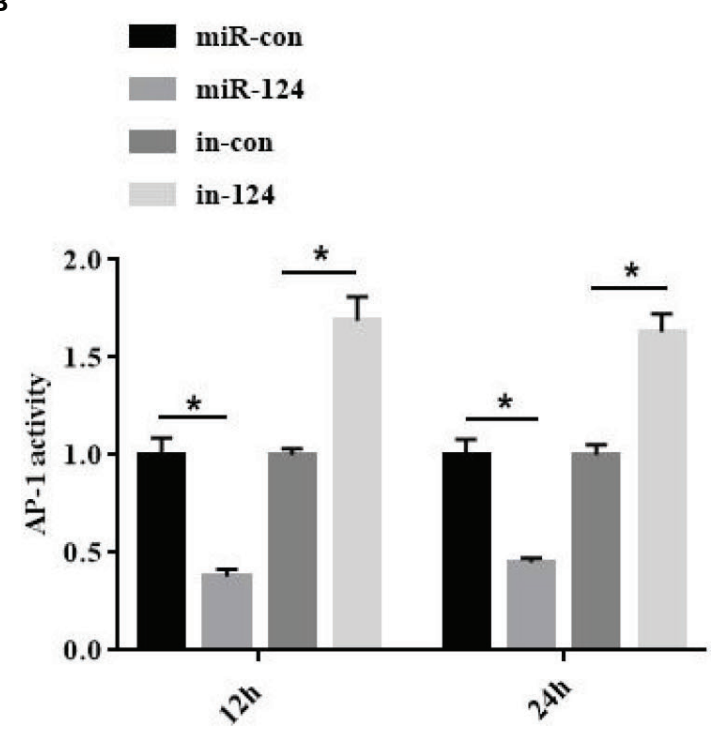

FIGURE 6 | MiR-124 inhibited NF-kB and activating protein-1 (AP-1) activation. The activities of NF-KB (A) and AP-1 (B) were analyzed by dual luciferase reporter assays. The miRNAs were transfected into the fathead minnow (FHM) cells in 24-well plates. After 24-h transfection, cells were infected with Singapore grouper iridovirus (SGIV) for 12 and $24 \mathrm{~h}$. Relative luciferase activity is measured as a ratio of firefly luciferase activity to Renilla luciferase activity. Control mimics, miR-con; miR-124 mimics, miR-124; control inhibitors, in-con; miR-124 inhibitors, in-124. All data are presented as mean $\pm S D, N=4$. Compared with the control group, significant difference of experimental group is indicated with * $(P<0.05)$.

The pathogenesis of virus is a complex process, which is the dynamic interaction of many host factors, such as miRNAs as the key factors. Viral infection can affect the expression of host miRNA. Litopenaeus vannamei miRNAs were differentially expressed after white spot syndrome virus (WSSV) infection, and the different expression of miRNAs could affect host signaling pathway of immune response (31). SGIV is an important virus of marine cultured fish causing huge financial losses, and SGIV infection can cause a series of host immune responses, including the changes of host miRNA expression (23). Previous studies in our lab have shown that the numbers of miRNA of E. coioides occurred with different expression responses to SGIV infection, and the expressions of some miRNAs were increased (7). In this study, miR-124 is upregulated during SGIV infection, indicating that miR-124 would be involved in SGIV infection and replication.

MiRNA could regulate viral infection (32). During viral infection, differential expression profiles of host miRNAs may lead to viral replication with feedback or feedforward effects (33). MiR-214 can directly interact with hepatitis E virus (HEV) RNA to enhance the replication and the genome translation of HEV, and the increase of HEV ORF2 level can upregulate the expression of miR-214 (34). MiR-1307 inhibits the replication of foot and mouth disease virus (FMDV) by the degradation of FMDV VP3 through proteasome pathway (35). In this study, SGIV infection can increase the expression of miR-124, and the upregulated miR-124 could not be involved in SGIV entry, but it could increase SGIV-induced CPE, and virus titers, transcription levels of SGIV genes, and the protein level of SGIV MCP, suggesting that miR-124 can be activated by SGIV infection, and the activated miR-124 could promote the replication of SGIV.

To further explore the roles of miR-124 in innate immune response of E. coioides, bioinformatics, gene mutants, Western blotting, etc., were used. By miRNA target prediction and the binding sties mutation of targeting genes, JNK3 and $\mathrm{p} 38 \alpha$ MAPK were important target genes of miR-124: the 3'-UTR of JNK3/ p38 $\alpha$ MAPK contained the matched binding sequence with miR124; miR-124 can downregulate the mRNA and protein JNK3/ p38 $\alpha$ MAPK, and JNK3/p38 $\alpha$ MAPK 3'-UTR-contained reporter. As members of MAPK family, JNK3 and p38 $\alpha$ MAPK can be activated; can convert the extracellular signals into intracellular signals by stress, viral infection, inflammatory cytokines, and mitotic factors (36-39); and can regulate the cell apoptosis and the viral replication (40-42). In mammals, miR124 regulates the expression of $\mathrm{p} 38 \alpha$ MAPK to participate in the neurons of signal transduction to translation machinery (43), and miR-124 regulates JNK to induce cell death in $\mathrm{CD}_{133^{+}}$HCC cells (44). Previous studies in our lab demonstrated that SGIV infection can induce the inflammation, and the immune response of host, causing the differential expression of host mRNA such as JNK and $\mathrm{p} 38 \alpha \operatorname{MAPK}(5,45)$. JNK and $\mathrm{p} 38 \alpha$ MAPK were the target genes of miR-124; the high expression of JNK and p38 MAPK would stimulate miR-124; and the expression of miR-124 was upregulated, suggesting that miR124 could regulate SGIV infection by targeting JNK3 and p38 $\alpha$ MAPK.

JNK and p38 MAPK could affect the activity of NF- $\kappa B$ and other transcription factors like AP-1 $(3,5,8,45)$. NF- $\mathrm{KB}$ plays key roles in response to various stress stimuli and is the main regulator and initiator of inflammatory response (46-48). 
A

A
管

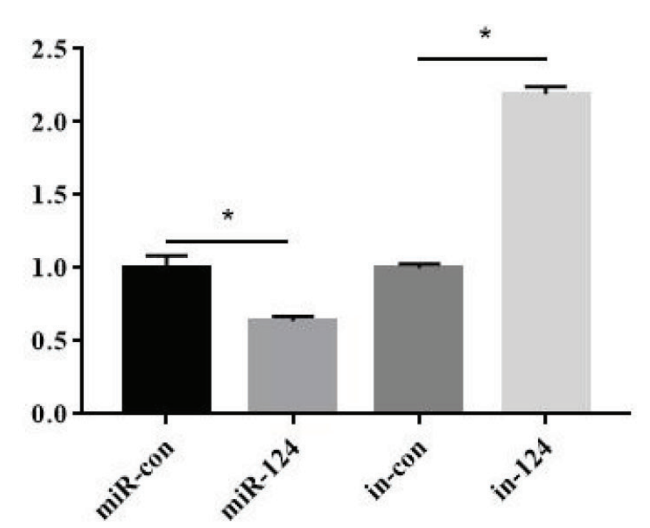

B

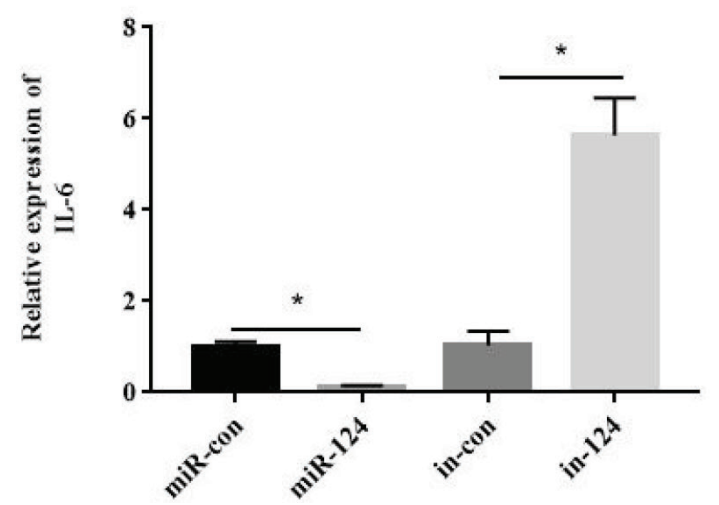

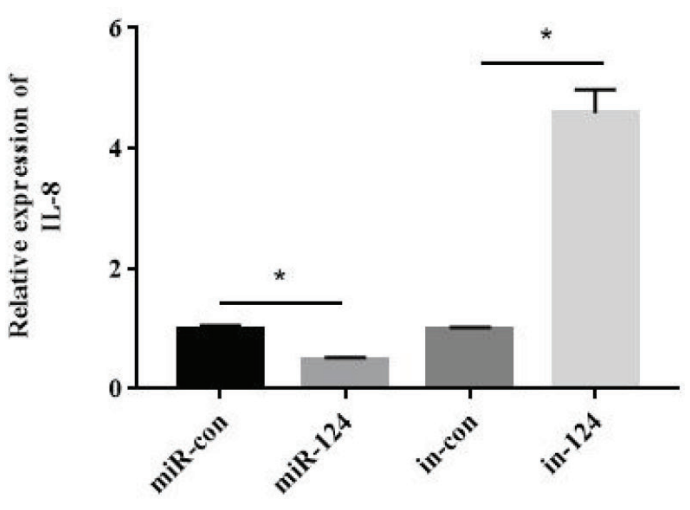

D

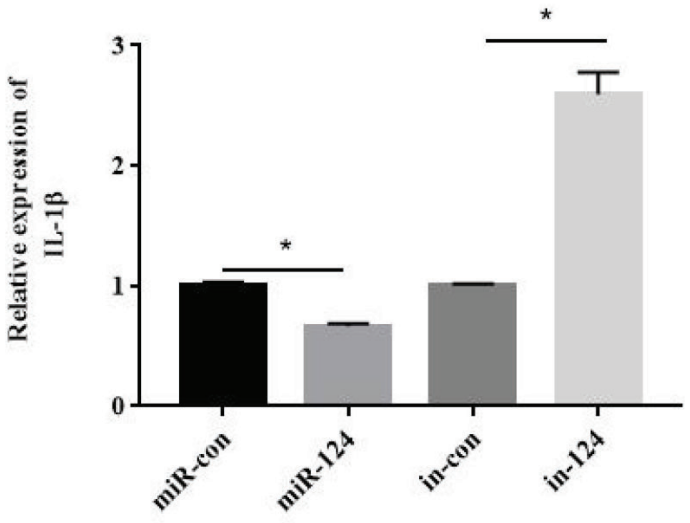

FIGURE 7 | The effect of miR-124 on the transcription of proinflammatory factors. $\beta$-Actin was used as internal reference. The transcription of TNF- $\alpha$ (A), IL-6

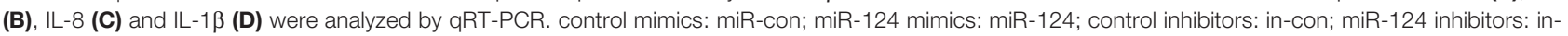
124. All data are presented as Mean $\pm \mathrm{SD}, \mathrm{N}=4$. Compared with the control group, significant difference of experimental group is indicated with * $(P<0.05)$.

Together with AP-1, the activated NF- $\mathrm{KB}$ participated in many cellular processes, including apoptosis, proliferation, and differentiation (49). The factors of TNF- $\alpha$, IL-1 $\beta$, IL- 6 , and IL- 8 are in synergy with cytokines, which are messengers of the inflammatory cascade $(50,51)$. In this study, the activation of NF- $\kappa B$ and AP- 1 and the expressions of the factors (TNF- $\alpha$, IL6 , IL-8, and IL-1 $\beta$ ) were significantly inhibited in miR-124overexpressing cells with SGIV infection, suggesting that miR124 inhibits the activity of $\mathrm{NF}-\kappa \mathrm{B}$ and $\mathrm{AP}-1$, and the expressions of the inflammatory factors to regulate the innate immunity.

Apoptosis is an innate cellular response to inflammatory response, transmission, and expression of virus. Virus has acquired the ability to regulate host cell apoptosis, control inflammatory response, and escape immune response (52). The Giant seaperch iridovirus (GSIV) ST kinase can activate caspase- 9 and caspase- 3 and induce the apoptosis (53). SGIV can induce typical apoptosis and increase the activities of caspase- 9 and caspase- 3 in FHM cells $(2,3,5,8,24)$. Both grouper miR-146a and miR-122 can reduce the SGIV-induced cell apoptosis and the activation of caspase- 9 and caspase- 3
$(8,23)$. To explore the roles of miR-124 in SGIV-induced apoptosis, apoptosis rates and the activation of caspase-9/3 were analyzed. A significant decrease of the SGIV-induced apoptosis was observed in the cells with overexpression miR124; the protein levels of caspase- 3 and cleaved caspase- 3 were reduced; and the activity of caspase-9/3 was significantly inhibited in miR-124-overexpressing cells. It has been demonstrated that p38 MAPK mediates the activity of caspase-8/9/3 in human umbilical vein endothelial cells when apoptosis is induced by PEDF; JNK was independently involved in the upregulation of caspase- 3 activity; and p38 MAPK was known to act as an upstream regulator of caspase- 3 in apoptotic endothelial cells (54-56). Since JNK and p38 MAPK can active caspase-9/3 and induce the cell apoptosis, and miR-124 here can deregulate the expression of JNK and p38 MAPK by targeting 3 '-UTR, we speculate that miR-124 might regulate the cell apoptosis and the activities of caspase- 9 and caspase- 3 via JNK and p38 MAPK.

In conclusion, in low vertebrates E. coioides, the roles of miR124 in SGIV infection and replication, and innate immune response were analyzed in this study. The expression level of 


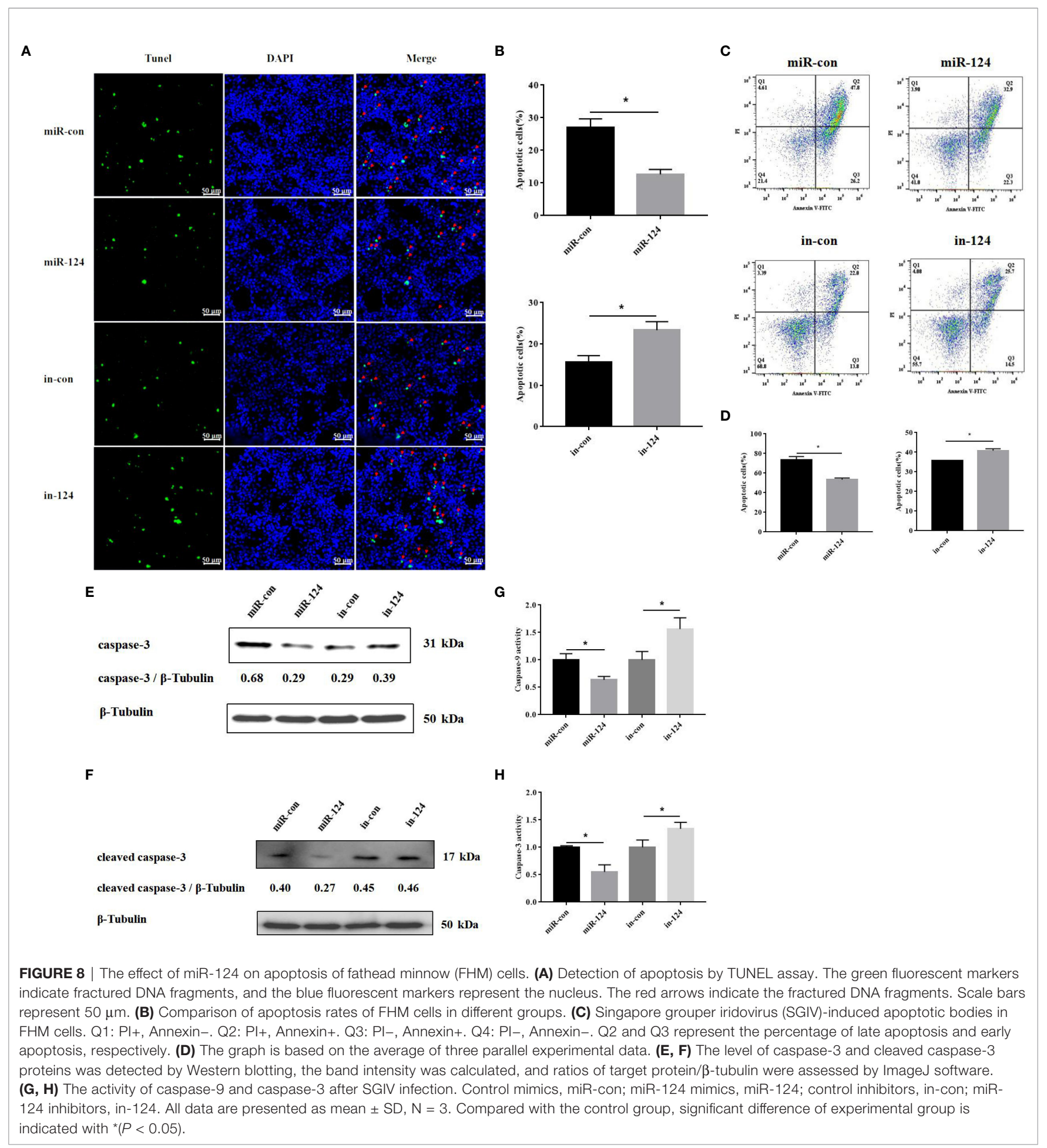

miR-124 was significantly upregulated during SGIV infection. Overexpression of miR-124 cannot affect SGIV entry but significantly increased SGIV-induced $\mathrm{CPE}$, viral replication, and the expressions of SGIV key genes. MiR-124 can inhibit the activities of NF- $\mathrm{KB}$ and AP-1, the expressions of inflammatory factors (TNF- $\alpha$, IL-6, IL-8, and IL-1 $\beta$ ), and the
SGIV-induced apoptosis by targeting $3^{\prime}$ UTR of JNK3 and p38 $\alpha$ MAPK. This study demonstrated that miR-124 was not related to SGIV entry but promotes SGIV replication and negatively regulates the innate immunity, which provides new insights into understanding the roles of fish miRNAs in virus pathogenesis. 


\section{DATA AVAILABILITY STATEMENT}

The datasets presented in this study can be found in online repositories. The names of the repository/repositories and accession number(s) can be found in the article/supplementary material.

\section{ETHICS STATEMENT}

The animal study was reviewed and approved by South China Agricultural University. Written informed consent was obtained from the owners for the participation of their animals in this study.

\section{AUTHOR CONTRIBUTIONS}

Q-WQ and H-YS conceived the experiments and reviewed the drafts of the manuscript. S-WW and L-QW contributed the

\section{REFERENCES}

1. Qin QW, Lam TJ, Sin YM, Shen H, Chang SF, Ngoh GH, et al. Electron Microscopic Observations of a Marine Fish Iridovirus Isolated From BrownSpotted Grouper, Epinephelus Tauvina. J Virol Methods (2001) 98(1):17-24. doi: 10.1016/S0166-0934(01)00350-0

2. Su YL, Chen JP, Mo ZQ, Zheng JY, Lv SY, Li PH, et al. A Novel MKK Gene (EcMKK6) in Epinephelus Coioides: Identification, Characterization and Its Response to Vibrio Alginolyticus and SGIV Infection. Fish Shellfish Immunol (2019) 92:500-7. doi: 10.1016/j.fsi.2019.06.043

3. Li PH, Liang YL, Su YL, Jiang YF, Chen B, Chen SY, et al. Molecular Characterization and Function Analysis of Epinephelus Coioides Hsp22 Response to SGIV and Vribro Alginolyticus Infection. Fish Shellfish Immunol (2020) 97:125-34. doi: 10.1016/j.fsi.2019.11.069

4. Li C, Yu YP, Zhang X, Wei JG, Qin QW. Grouper Atg12 Negatively Regulates the Antiviral Immune Response Against Singapore Grouper Iridovirus (SGIV) Infection. Fish Shellfish Immunol (2019) 93:702-10. doi: 10.1016/ j.fsi.2019.08.037

5. Guo M, Wei JG, Zhou YC, Qin QW. C-Jun N-Terminal Kinases 3 (JNK3) From Orange-Spotted Grouper, Epinephelus Coioides, Inhibiting the Replication of Singapore Grouper Iridovirus (SGIV) and SGIV-Induced Apoptosis. Dev Comp Immunol (2016) 65:169-81. doi: 10.1016/ j.dci.2016.06.009

6. Xia LQ, Liang HY, Huang YH, Ou-Yang Z, Qin QW. Identification and Characterization of Singapore Grouper Iridovirus (SGIV) ORF162L, an Immediate-Early Gene Involved in Cell Growth Control and Viral Replication. Virus Res (2009) 147(1):30-9. doi: 10.1016/j.virusres.2009.09.015

7. Guo CY, Cui HC, Ni SW, Yan Y, Qin QW. Comprehensive Identification and Profiling of Host miRNAs in Response to Singapore Grouper Iridovirus (SGIV) Infection in Grouper (Epinephelus Coioides). Dev Comp Immunol (2015) 52(2):226-35. doi: 10.1016/j.dci.2015.05.014

8. Sun HY, Su YL, Li PH, He JY, Qin QW. The Roles of Epinephelus Coioides miR-122 in SGIV Infection and Replication. Mar Biotechnol (2021) 23:294307. doi: 10.1007/s10126-021-10023-w

9. Fabian MR, Sonenberg N, Filipowicz W. Regulation of mRNA Translation and Stability by microRNAs. Annu Rev Biochem (2010) 79:351-79. doi: 10.1146/annurev-biochem-060308-103103

10. Lee RC, Feinbaum RL, Ambros V. The C. Elegans Heterochronic Gene Lin-4 Encodes Small RNAs With Antisense Complementarity to Lin-14. Cell (1993) 75(5):843-54. doi: 10.1016/0092-8674(93)90529-y

11. Wightman B, Ha I, Ruvkun G. Posttranscriptional Regulation of the Heterochronic Gene Lin-14 by Lin- 4 Mediates Temporal Pattern Formation in C. Elegans. Cell (1993) 75(5):855-62. doi: 10.1016/0092-8674(93)90530-4

12. Reinhart BJ, Slack FJ, Basson M, Pasquinelli AE, Bettinger JC, Rougvie AE, et al. The 21-Nucleotide Let-7 RNA Regulates Developmental Timing in materials/analysis tools. P-HL wrote the manuscript, conducted the experiment, and analyzed the data. All authors contributed to the article and approved the submitted version.

\section{FUNDING}

This work was funded by National Natural Science Foundation of China (U20A20102, 31930115), Innovation Group Project of Southern Marine Science and Engineering Guangdong Laboratory (Zhuhai) (311021006), the China Agriculture Research System of MOF and MARA (CARS-47-G16), Marine Fisheries Bureau Key funds and marine projects (GDME2018C002), the National Key R\&D Program of China (2018YFD0900501 and 2018YFC0311302).
Caenorhabditis Elegans. Nature (2000) 403(6772):901-6. doi: 10.1038/ 35002607

13. Lagos-Quintana M, Rauhut R, Lendeckel W, Tuschl T. Identification of Novel Genes Coding for Small Expressed RNAs. Science (2001) 294:853-8. doi: 10.1126/science.1064921

14. Lau NC, Lim LP, Weinstein EG, Bartel DP. An Abundant Class of Tiny RNAs With Probable Regulatory Roles in Caenorhabditis Elegans. Science (2001) 294:858-62. doi: 10.1126/science.1065062

15. Lee RC, Ambros V. An Extensive Class of Small RNAs in Caenorhabditis Elegans. Science (2001) 294:862-4. doi: 10.1126/science.1065329

16. Zhang C, Tu JG, Zhang YA. MicroRNA Regulation of Viral Replication in Teleost Fish: A Review. Rev Aquacult (2021) 13:1367-78. doi: 10.1111/ raq. 12526

17. Zhang C, Feng S, Zhang W, Chen N, Hegazy AM, Chen W, et al. MicroRNA miR-214 Inhibits Snakehead Vesiculovirus Replication by Promoting IFN-A Expression via Targeting Host Adenosine 5'-Monophosphate-Activated Protein Kinase. Front Immunol (2017) 8:1775. doi: 10.3389/fimmu.2017.01775

18. Zhang B, Zhou Z, Sun L. pol-miR-731, a Teleost miRNA Upregulated by Megalocytivirus, Negatively Regulates Virus-Induced Type I Interferon Response, Apoptosis, and Cell Cycle Arrest. Sci Rep (2016) 6:28354. doi: 10.1038/srep28354

19. Lang Q, Ling C. MiR-124 Suppresses Cell Proliferation in Hepatocellular Carcinoma by Targeting PIK3CA. Biochem Biophys Res Commun (2012) 426 (2):247-52. doi: 10.1016/j.bbrc.2012.08.075

20. Cheng LC, Pastrana E, Tavazoie M, Doetsch F. miR-124 Regulates Adult Neurogenesis in the Subventricular Zone Stem Cell Niche. Nat Neurosci (2009) 12(4):399-408. doi: 10.1038/nn.2294

21. Makeyev EV, Zhang JW, Carrasco MA, Maniatis T. The MicroRNA miR-124 Promotes Neuronal Differentiation by Triggering Brain-Specific Alternative Pre-mRNA Splicing. J Mol Cell (2007) 27(3):435-48. doi: 10.1016/ j.molcel.2007.07.015

22. Mccaskill JL, Ressel S, Alber A, Redford J, Power UF, Schwarze J, et al. BroadSpectrum Inhibition of Respiratory Virus Infection by MicroRNA Mimics Targeting P38 MAPK Signaling. Mol Ther Nucleic Acids (2017) 7:256-66. doi: 10.1016/j.omtn.2017.03.008

23. Ni S, Yan Y, Cui H, Yu Y, Qin Q. Fish miR-146a Promotes Singapore Grouper Iridovirus Infection by Regulating Cell Apoptosis and NF-kB Activation. J Gen Virol (2017) 98:1489. doi: 10.1099/jgv.0.000811

24. Huang XH, Huang YH, Ouyang ZL, Xu LX, Yang Y, Cui HC, et al. Singapore Grouper Iridovirus, a Large DNA Virus, Induces Nonapoptotic Cell Death by a Cell Type Dependent Fashion and Evokes ERK Signaling. Apoptosis (2011) 16:831-45. doi: 10.1007/s10495-011-0616-y

25. Guo L, Sun B, Sang F, Wang W, Lu Z. Haplotype Distribution and Evolutionary Pattern of miR-17 and miR-124 Families Based on Population Analysis. PloS One (2009) 4(11):e7944. doi: 10.1371/journal.pone.0007944 
26. Weng R, Cohen SM. Drosophila miR-124 Regulates Neuroblast Proliferation Through Its Target Anachronism. Development (2012) 139:1427-34. doi: 10.1371/journal.pone.0007944

27. Aksoy-Aksel A, Zampa F, Schratt G. MicroRNAs and Synaptic Plasticity-a Mutual Relationship. Philos Trans R Soc Lond Ser B Biol Sci (2014) 369(1652): 20130515. doi: 10.1098/rstb.2013.0515

28. Follert P, Cremer H, Beclin C. MicroRNAs in Brain Development and Function: A Matter of Flexibility and Stability. Front Mol Neurosci (2014) 7:5. doi: $10.3389 /$ fnmol.2014.00005

29. Krichevsky AM, King KS, Donahue CP, Khrapko K, Kosik KS. A microRNA Array Reveals Extensive Regulation of microRNAs During Brain Development. RNA (2003) 9:1274-81. doi: 10.1261/rna.5980303

30. Zhang X, Lei B, Yuan Y, Zhang L, Qi H. Brain Control of Humoral Immune Responses Amenable to Behavioural Modulation. Nature (2020) 581:204-8. doi: 10.1038/s41586-020-2235-7

31. Wu WL, Dai CJ, Duan XW, Wang CF, Lin XS, Ke JY, et al. MiRNAs Induced by White Spot Syndrome Virus Involve in Immunity Pathways in Shrimp Litopenaeus Vannamei. Fish Shellfish Immunol (2019) 93:743-51. doi: 10.1016/j.fsi.2019.08.009

32. Trobaugh DW, Klimstra WB. MicroRNA Regulation of RNA Virus Replication and Pathogenesis. Trends Mol Med (2017) 23:80-93. doi: 10.1016/j.molmed.2016.11.003

33. Mehinto AC, Martyniuk CJ, Spade DJ, Denslow ND. Applications for NextGeneration Sequencing in Fish Ecotoxicogenomics. Front Genet (2012) 3:62. doi: 10.3389/fgene.2012.00062

34. Rajashree NP, Yogesh AK. Uncovering the Roles of miR-214 in Hepatitis E Virus Replication. J Mol Biol (2020) 432(19):5322-42. doi: 10.1016/j.jmb.2020.07.015

35. Qi LL, Wang KL, Chen HT, Liu XS, Lv JL, Hou ST, et al. Host microRNA miR1307 Suppresses Foot-and-Mouth Disease Virus Replication by Promoting VP3 Degradation and Enhancing Innate Immune Response. J Virol (2019) 535:162-70. doi: 10.1016/j.virol.2019.07.009

36. Cargnello M, Roux PP. Activation and Function of the MAPKs and Their Substrates, the MAPK-Activated Protein Kinases. Microbiol Mol Biol Rev (2011) 75(1):50-83. doi: 10.1128/MMBR.00031-10

37. Du Y, Taylor CG, Aukema HM, Zahradka P. Regulation of Docosahexaenoic Acid-Induced Apoptosis of Confluent Endothelial Cells: Contributions of Mapks and Caspases. BBA-Mol Cell Biol L (2021) 1866(5):158902. doi: 10.1016/j.bbalip.2021.158902

38. Kyriakis JM, Avruch J. Mammalian Mitogen-Activated Protein Kinase Signal Transduction Pathways Activated by Stress and Inflammation. Physiol Rev (2001) 81:807-69. doi: 10.1007/s004240100541

39. Raingeaud J, Gupta S, Rogers JS, Dickens M, Han J, Ulevitch RJ, et al. ProInflammatory Cytokines and Environmental Stress Cause P38 MitogenActivated Protein Kinase Activation by Dual Phosphorylation on Tyrosine and Threonine. J Biol Chem (1995) 270:7420-6. doi: 10.1074/jbc.270.13.7420

40. Clarke P, Meintzer SM, Wang Y, Moffitt LA, Richardson-Burns SM, Johnson GL, et al. JNK Regulates the Release of Proapoptotic Mitochondrial Factors in Reovirus-Infected Cells. J Virol (2004) 78(23):13132-8. doi: 10.1128/ JVI.78.23.13132-13138.2004

41. Hirasawa K, Kim A, Han HS, Han J, Jun HS, Yoon JW. Effect of P38 MitogenActivated Protein Kinase on the Replication of Encephalomyocarditis Virus. J Virol (2003) 77(10):5649. doi: 10.1128/JVI.77.10.5649-5656.2003

42. Holloway G, Coulson BS. Rotavirus Activates JNK and P38 Signaling Pathways in Intestinal Cells, Leading to AP-1-Driven Transcriptional Responses and Enhanced Virus Replication. J Virol (2006) 80:10624-33. doi: 10.1128/JVI.00390-06

43. Lawson SK, Dobrikova EY, Shveygert M, Gromeier M. P38 $\alpha$ MitogenActivated Protein Kinase Depletion and Repression of Signal Transduction to Translation Machinery by miR-124 and -128 in Neurons. Cell Mol Biol (2013) 33(1):127-35. doi: 10.1128/MCB.00695-12

44. Xu Y, Lai Y, Weng H, Tan L, Ye Y. Mir-124 Sensitizes Cisplatin-Induced Cytotoxicity Against Cd133+ Hepatocellular Carcinoma Cells by Targeting
Sirt1/Ros/Jnk Pathway. Aging (2019) 11(9):2551-64. doi: 10.18632/ aging. 101876

45. Huang X, Huang Y, Ou-Yang Z, Cai J, Qin QW. Roles of Stress-Activated Protein Kinases in the Replication of Singapore Grouper Iridovirus and Regulation of the Inflammatory Responses in Grouper Cells. J Gen Virol (2011) 92(6):1292. doi: 10.1099/vir.0.029173-0

46. Pasporakis M. Regulation of Tissue Homeostasis by NF-kB Signalling: Implications for Inflammatory Disease. Nat Rev Immunol (2009) 9(11):77888. doi: $10.1038 /$ nri2655

47. Bonizzi G, Karin M. The Two NF-Kb Activation Pathways and Their Role in Innate and Adaptive Immunity. Trends Immunol (2004) 25:280-8. doi: 10.1016/j.it.2004.03.008

48. Ghosh S, Hayden MS. New Regulators of NF-kappaB in Inflammation. J Immunol (2008) 8:837-48. doi: 10.1038/nri2423

49. Yue J, Chang S, Xiao Z, Qi YJ. The Protective Effect of Puerarin on Angiotensin II-Induced Aortic Aneurysm Formation by the Inhibition of NADPH Oxidase Activation and Oxidative Stress-Triggered AP-1 Signaling Pathways. Oncol Lett (2018) 16:3327-32. doi: 10.3892/ol.2018.9021

50. Merviel P, Carbillon L, Challier JC, Rabreau M, Beaufils M, Uzan S. Pathophysiology of Preeclampsia: Links With Implantation Disorders. Euro J Obstet Gynecol (2004) 115:134-47. doi: 10.1016/j.ejogrb.2003.12.030

51. Jonsson Y, Ruber M, Matthienssen L, Berg G, Nieminen K, Sharma S, et al. Cytokine Mapping of Sera From Women With Preeclampsia and Normal Pregnancies. J Reprod Immunol (2006) 70:83-91. doi: 10.1016/ j.jri.2005.10.007

52. Galluzzi L, Brenner C, Morselli E, Touat Z, Kroemer G. Viral Control of Mitochondrial Apoptosis. PloS Pathog (2008) 4:1000018. doi: 10.1371/ journal.ppat.1000018

53. Reshi L, Wu HC, Wu JL, Wang HV, Hong JR. GSIV Serine/Threonine Kinase can Induce Apoptotic Cell Death via P53 and Pro-Apoptotic Gene Bax Upregulation in Fish Cells. Apoptosis (2016) 21:443-58. doi: 10.1007/ s10495-016-1219-4

54. Chen L, Zhang SS, Barnstable CJ, Tombran-Tink J. PEDF Induces Apoptosis in Human Endothelial Cells by Activating P38 MAP Kinase Dependent Cleavage of Multiple Caspases Biochem. Biophys Res Commun (2006) 348:1288-95. doi: 10.1016/j.bbrc.2006.07.188

55. Chaudhury H, Zakkar M, Boyle J, Cuhlmann S, van der Heiden K, Luong le A, et al. C-Jun N-Terminal Kinase Primes Endothelial Cells at Atheroprone Sites for Apoptosis. Arterioscler Thromb Vasc Biol (2010) 30:546-53. doi: 10.1161/ ATVBAHA.109.201368

56. Jiang DJ, Jia SJ, Dai Z, Li YJ. Asymmetric Dimethylarginine Induces Apoptosis via P38 MAPK/caspase-3-Dependent Signaling Pathway in Endothelial Cells. J Mol Cell Cardiol (2006) 40:529-39. doi: 10.1016/j.yjmcc.2006.01.021

Conflict of Interest: The authors declare that the research was conducted in the absence of any commercial or financial relationships that could be construed as a potential conflict of interest.

Publisher's Note: All claims expressed in this article are solely those of the authors and do not necessarily represent those of their affiliated organizations, or those of the publisher, the editors and the reviewers. Any product that may be evaluated in this article, or claim that may be made by its manufacturer, is not guaranteed or endorsed by the publisher.

Copyright $\odot 2021 \mathrm{Li}$, Wang, He, Zhu, Huang, Wang, Qin and Sun. This is an openaccess article distributed under the terms of the Creative Commons Attribution License (CC BY). The use, distribution or reproduction in other forums is permitted, provided the original author(s) and the copyright owner(s) are credited and that the original publication in this journal is cited, in accordance with accepted academic practice. No use, distribution or reproduction is permitted which does not comply with these terms. 